$$
\begin{aligned}
& (0.0,11.0), 000 \\
& 132000^{\circ} \text {. PE-12O } \\
& 55^{\circ} 3 x^{\circ} \quad P E-120-12 \\
& \text { TERRITURY OF ALAEKA }
\end{aligned}
$$

DEPARTMENT DF MINES

$$
1.9
$$

December 11, 1952

\title{
IEHORADDUR REPORI
}

To: Phil R. Holdsworth, Commissioner of Mines

TROW: James is. Williams, 4ssociate lining Engineer $k \times 120-9$

SUBJECT: Examination of the Novatney gold lode prospect, Helm Bay, Ketchikan Precinct, September 20, 1952.

After receiving a sample of panned gold concentrate from in. Robert Novatney of Juneau that was assayed and found to contain high values, it was decided that an examination of his prospect should be made to determine the possibilities of the property and assist him with technical advice if possible. Accordingly, the examination was made on September 20, 1952 by Árthur K. Hover, Tungineer-issayer of the Ketchikan assay Office, and the writer. The prospect consists of an open cut exposing narrow quarta veins strileing with, but dpping against, the country rock which is a soft schist of two varieties. Mineralization is in the form of auriferous pyrite, which is disseminated through the quartz and schist alike. Yalues are low.

Mr. Hovatnej's propertyr consists of three clains, recorded in Ketchikan as jiller Ledge and Lode ko's. 1, 2, and 3. Iis wife, 
TERRITURY DF ALASKA

DEPARTMENT $\square$ F MINES

JUNEAU, ALASKA

Mrs. Dorothy Novainey, is his partner in the property. The pit in which the veins are exposed is on Claim No. 1. The prospect was discovered accidentally by a Lloyd (?) Miller while huntine. He gave up the property and Novatney relocated it in 1933.

The property is situated on the west side of Helm Bay within a few hundred feet of the top of the north slope of cold Mountain. The approximate location is shown in Figure 1. A Paulin anerold altimeter showed the elevation to be about 1450 feet. in old corduroy road leads from the beach to a cabin at 500 feet in elevation where Novatney lives while working his prospect. Trom this cabin the trail leads to the risht across a small stream and then cilmbs steeply to the prospect. A second good cabin is on the beach at the bottom of the corduroy road. Stbout a mile to the south from this point is an excellent dock maintained by the covernment and a third good cabin. The locition is about 25 miles airline distance Nij of Ketchikan and the geographical coordinates are approximately $232^{\circ} 00^{\prime}$ : Ions and $55^{\circ} 38^{\prime}$ in Lat. The topography, timber, and climate in the vicinity of Helm Bay are typical of the southern part of Si xlaska along the inland waters. The slopes are quite steep, and the mountains rise to about 2000 feet around the bay. I'he timber is mostly small, but it covers the slopes except for occasional open muskeg meadows. is usual, the ground is wet and soft nearly everywhere. "lhe clinate is comparatively mild for slaski, but precipitation is high, and 


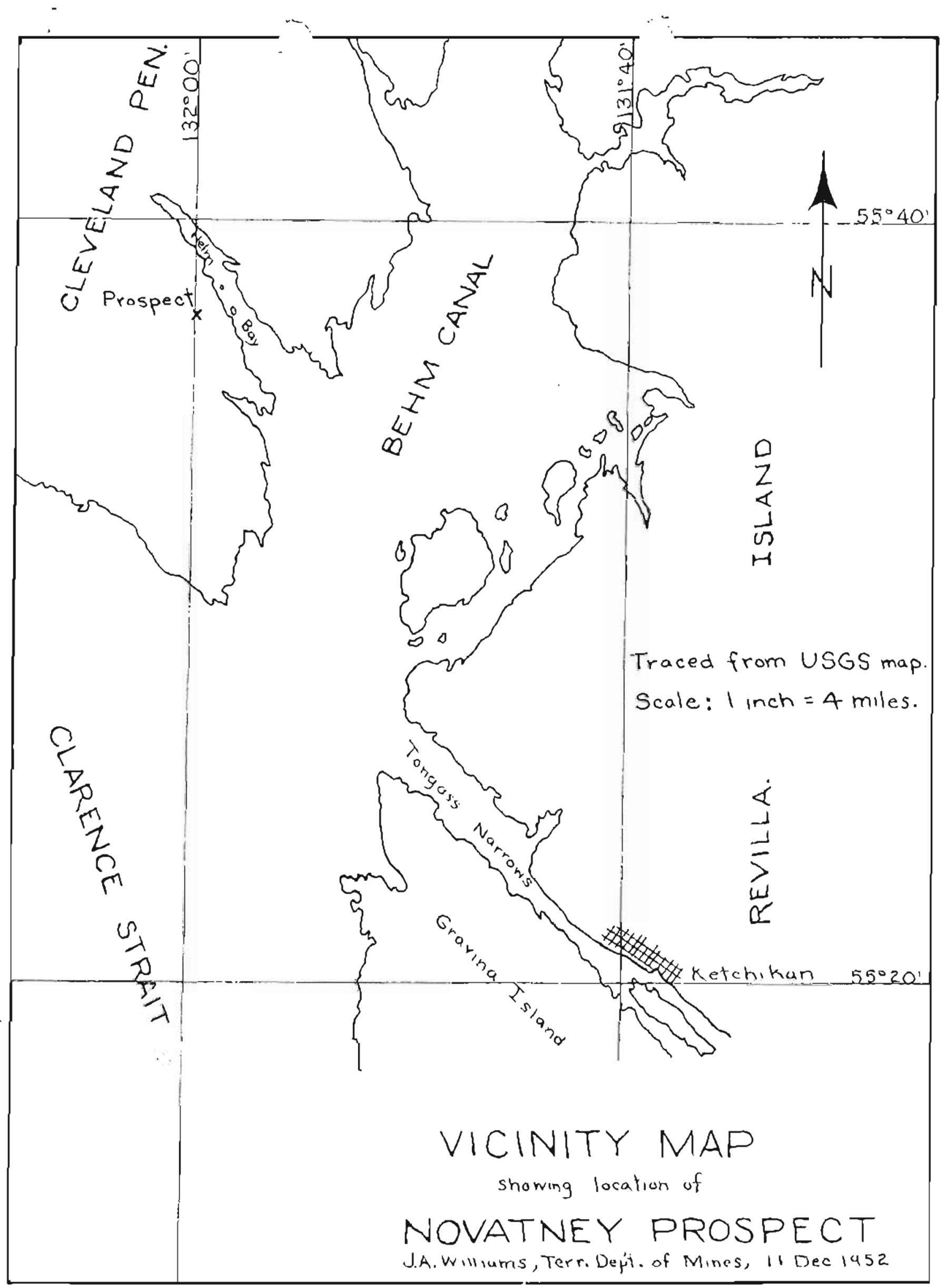

Figure 1. 
TERRITLRY DF ALASKA

DEPARTMENT DF MINES

JUNEAU, ALASKA

the snow at the elevation of the prospect hangs on until late spring or early surmer.

The workings of the prospect consist of an open pit about 100 feet long which has exposed the mineralization. The geology consists of rather narrov quartz veins ruming through two varieties of steeply dipping soft schist. The veins and the bedding planes of the schist both strike about $N 40^{\circ} \mathrm{W}$, but the veins dip from $30^{\circ} \mathrm{NW}$ to vertical while the schlst dips from $40^{\circ}$ to $70^{\circ} \mathrm{SE}$. The two varieties of schist are a brow schist and a. greenstone variety. There has been movement between the two schists in ono place as shown in Figure 2 which is a photograph of the vertical face in the pit where the attitude of the schist can be seen best. The geology can also be seen in Figures 3, 4, 5, and 6. The quartz vein in the photos is the large one in the Ni' part of the open cut. The schist is relatively undisturbed except for the tilting, and the quartz is quite free from stains or discoloration.

Between two of the strata of schist there has been a bedding plane movement (see Figure 2) which raises the question as to whether the two veins indicated in Figure 6 might not be the same, If the fault is normal. This question is undecided. The mineralogy is apparently simple. Fine pyrites are included in the quartz and schisi alike, and the pyrites carry the gold. A panned concentrate from this prospect showed no free gold 


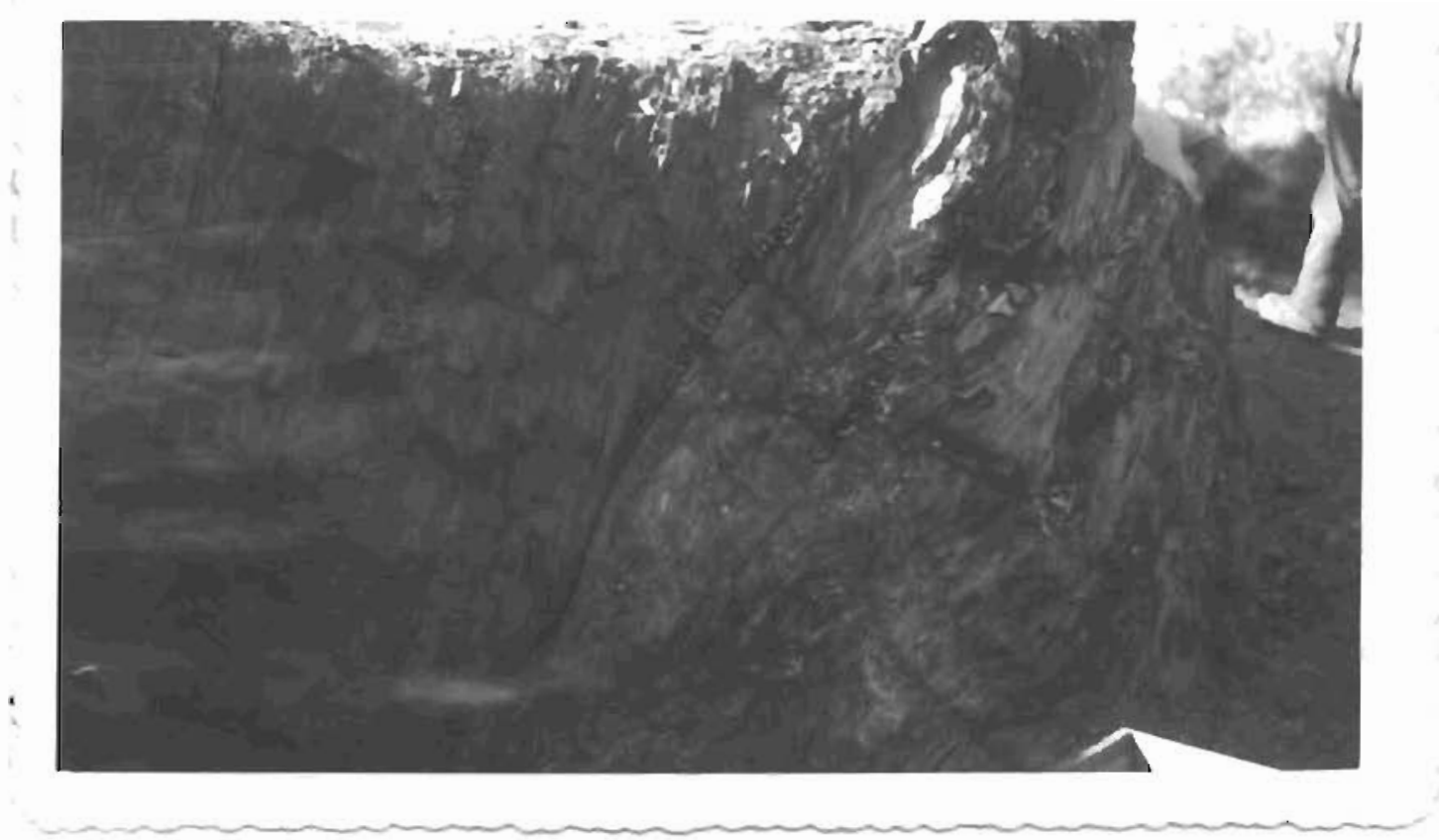

Figure 2. Photo of main pit, face where schist was sampled and fault plane is shown.

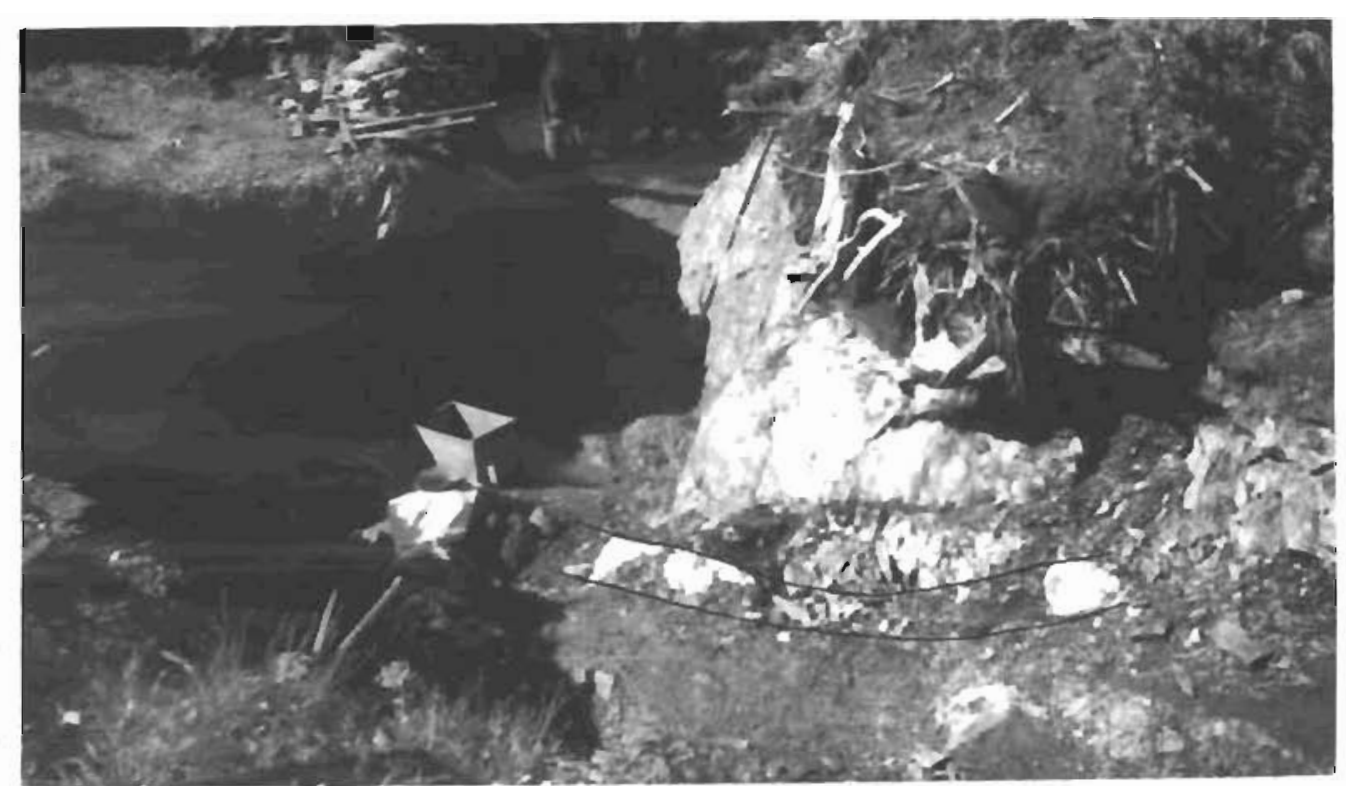

Tigure 3. Photo taken toward and beyond pit face and showing outline of part of largest quartz vein. 


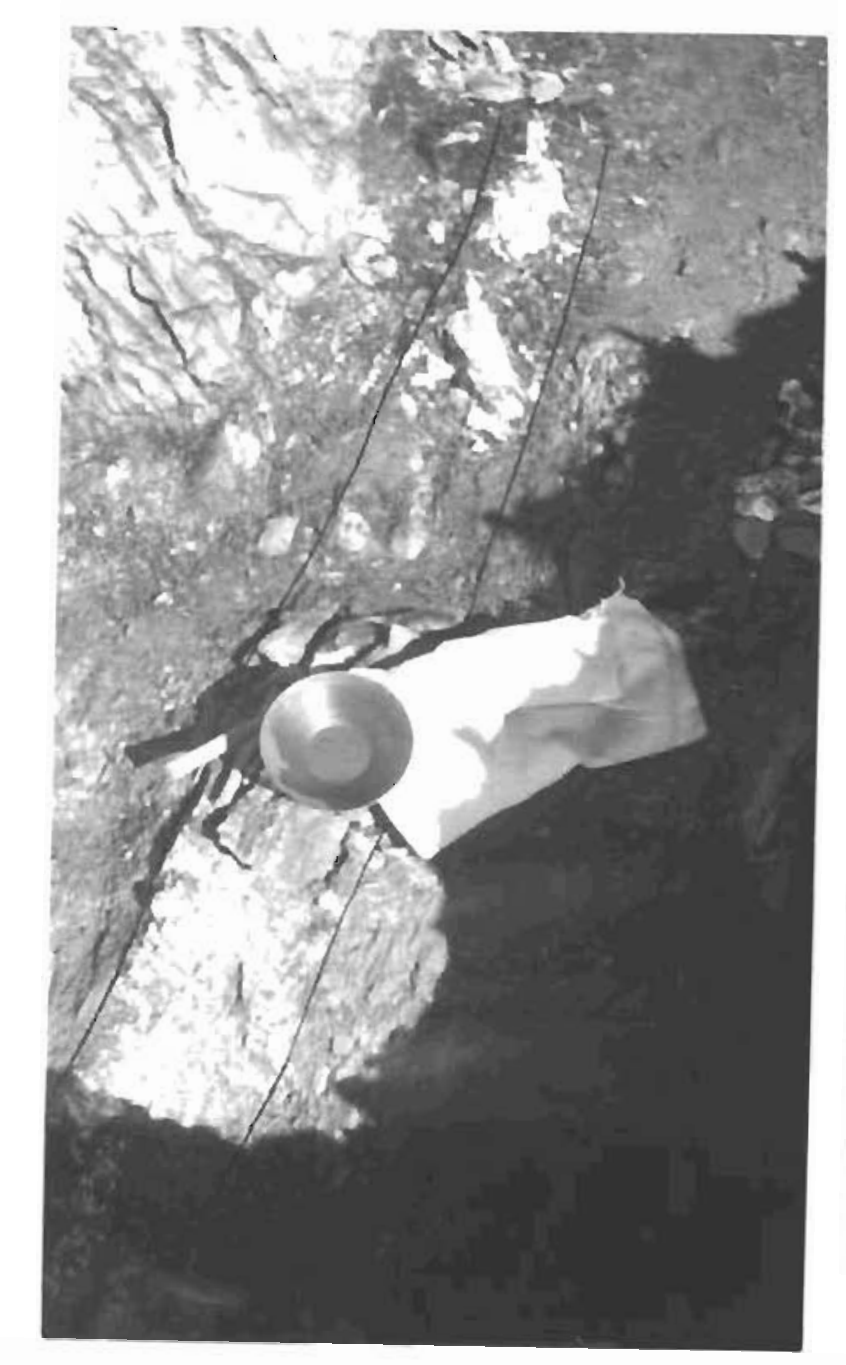

-

Figure 4. Nearly vertical. view of largest vein from top of pit face. Sample JW52-43 taken about midway between gold pan and bottom of photo

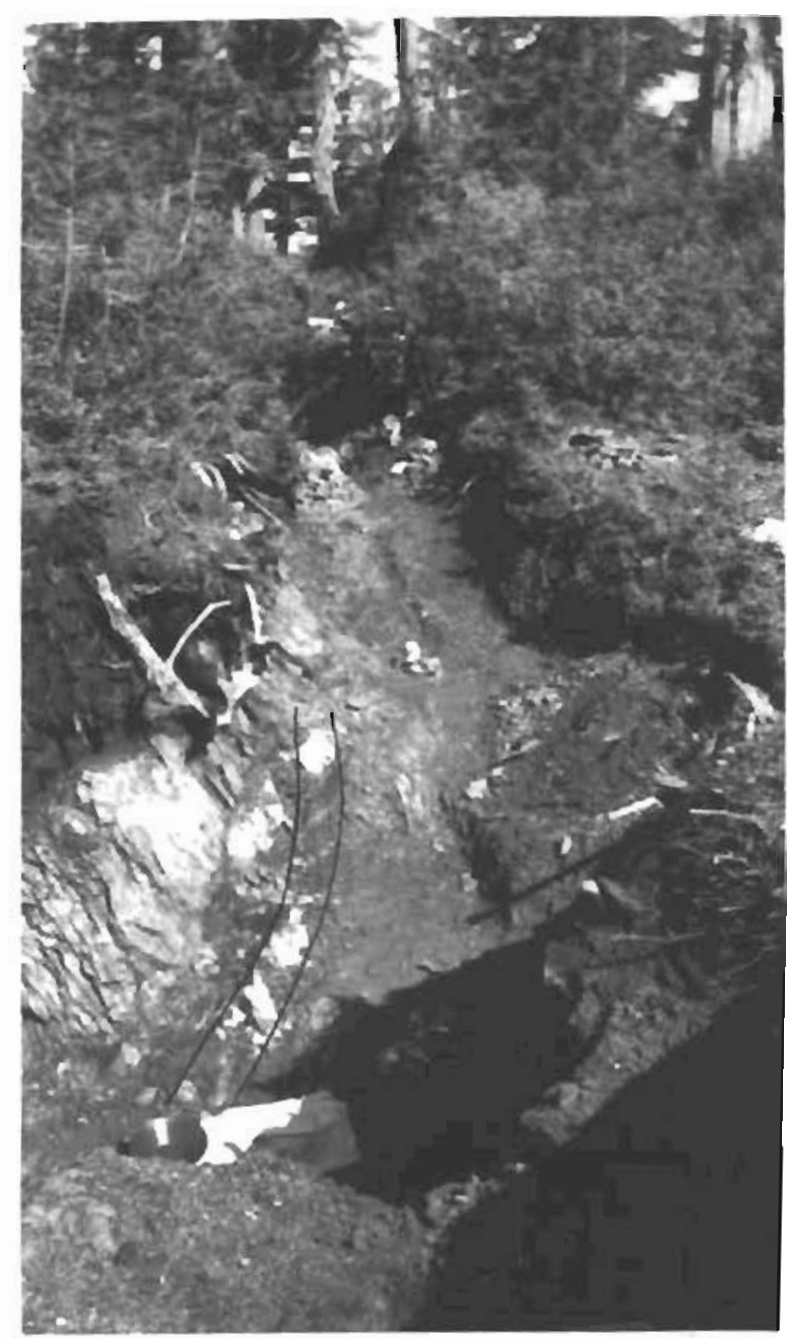

Figure 5. Another view of largest vein from top of pit face looking toward $\mathrm{N}$ end of pit. 


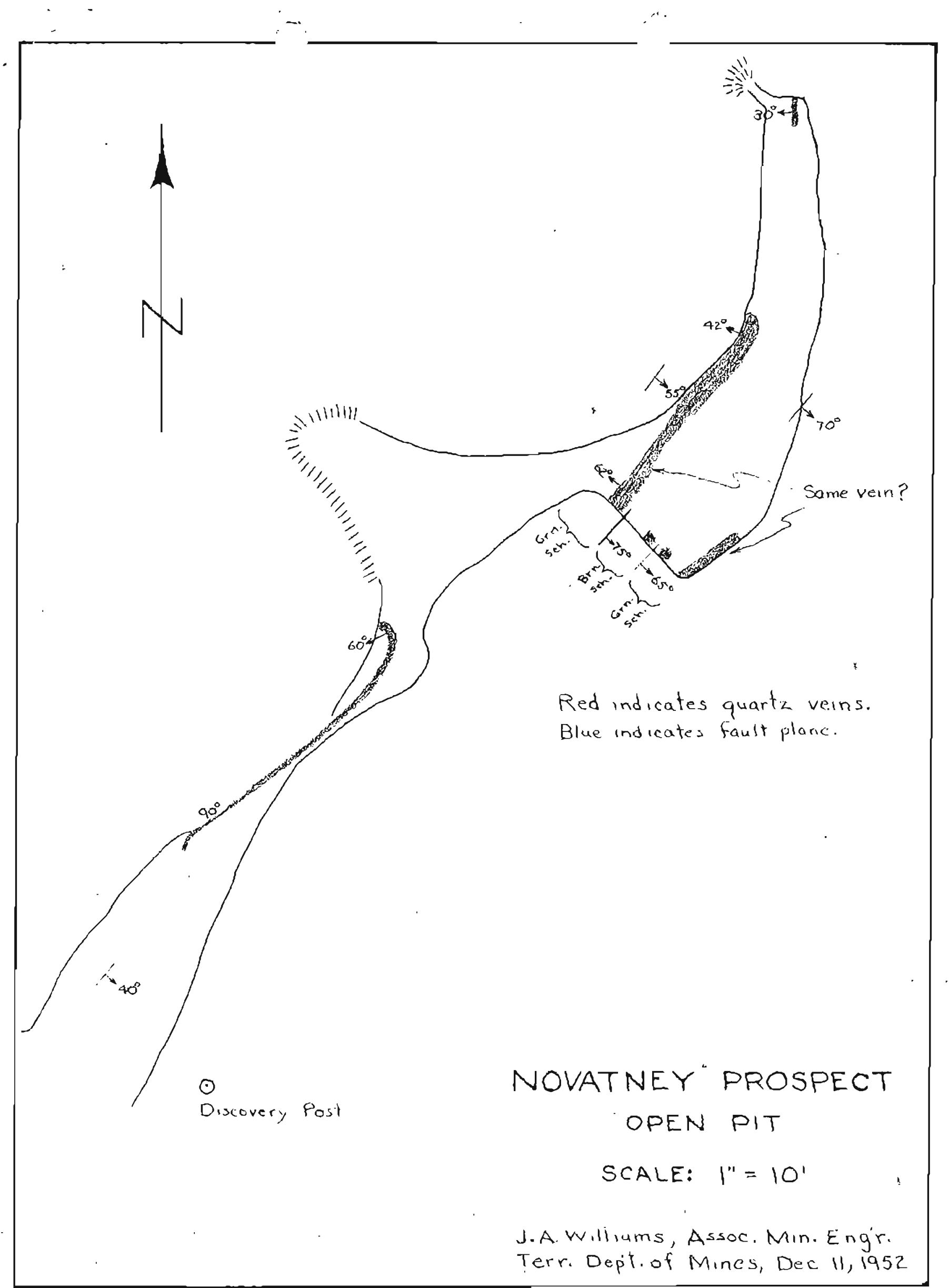

Figure 6. 
TERRITIRY DF ALASKA

DEPARTMENT DF MINES

IUNEAU, ALASKA

under the microscope, but assayed an average of 12.97 ounces of gold per ton and 2.86 ounces of silver. The concentration ratio was necessarily high, for the channel samples showed the quartz and schist values to be low. It was thought at first that there was more gold in the schist than in the quarta, since the pyrites could be seen in the schist and the quartiz appeared barren. The sampling proved this assumption false. The values are just slightly higher in the quartz than in the schlst where sampled.

Six Channel samples were cut in the exposures. Ji:J2-37 and 38 were cut from the two ends of the southern-most quartz vein. Ju52-39, 40, and 41 were cut from the schist at right angles to the dip across the main pit face pictured in figure 2. JW52-43 was cut from the largest vein in a place just $30^{\prime \prime}$ from the pit face. Glover assayed these samples at Ketchikan rith the following results:

\begin{tabular}{|c|c|c|c|c|}
\hline Sample & Iocation & width & Oz. $4 \mathrm{u} / \mathrm{ton}$ & Value@ \\
\hline $5.152-37$ & $N$ end $S$ qtz vein & $12^{\prime \prime}$ & I'race & - \\
\hline $3, \sqrt{5} 2-38$ & $s$ end $s$ qtz vein & $6^{\prime \prime}$ & 0.04 & 部 1.4 .0 \\
\hline J1152-39 & Brm schist & 421 & 0.02 & 0.70 \\
\hline$J: \pi / 2-40$ & Grm schist & $22^{* 11}$ & I'race & $-\infty$ \\
\hline$J: 52-41$ & Grn schist & 1911 & 0.01 & 0.35 \\
\hline$J=52-4 ! 3$ & $\begin{array}{l}S \text { end } N \text { qtz vein } \\
\text { isl samples were }\end{array}$ & $\begin{array}{l}18^{\prime \prime} \\
\text { in } \mathrm{sil}\end{array}$ & 0.03 & 3.05 \\
\hline
\end{tabular}




\section{TERRITDRY IF ALASKA \\ DEPARTMENT DF MINES \\ JUNEAU, ALASKA}

pieces of likely-looking float was picked up along this stream (Ji52-42), but the values were trace and niz.

Vir. Kovatney brought a sample to the Ketchilkan office at the close of the season that he reported represented 17 fieet of ground. This assayed at 0.06 ounces of gold per ton. He announced that he intended to continue development on his property next year in the expectation of striking high grade ore. The writer does not share this optimism, but there is a chance that the values may improve if the property iere to be trenched perpendicular to the strike and atsay from the existing open cut.

In addition to $\mathrm{r}$. Novatney, Glover and the miter were accompanied on the examination by Joe Houston and Robert Valikinje of the U.S. Geological Survey Trace dements Unit, and Harry Tomsend, widely-known Consulting Wining Geologist for inaconda. Mr. Tormsend's help and excellent advice were greatly appreciated and are hereby acknowledged. Appreciation and acknowledgment are also dize the USCS men for the transportation furnished to lielm Bay, and to fir. Novatrey for his cordial and generous hospitality during the time spent on his property.

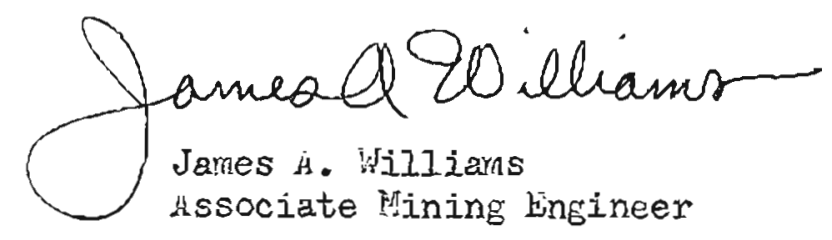

Hig 